\title{
Where have you been? CGI film stars and reanimation horrors ...
}

\author{
In a moment of fantastic whim I whispered questions to the reddening \\ ears; questions of other worlds of which the memory might still be present. \\ Subsequent terror drove them from my mind, but I think the last one, which I \\ repeated, was: 'Where have you been?' \\ HP Lovecraft, 'Herbert West - Reanimator'
}

Cal Trask: Hey Aron, why don't you ask me where I've been? Aron Trask: Would you tell me?

Cal Trask: No.

East of Eden (1955), directed by Elia Kazan, starring James Dean (Cal Trask) and Richard Davalos (Aron Trask)

In late 2019, cinephiles reacted to the news that James Dean would be starring in a new film, an adaptation of Gareth Crocker's 2013 novel, Finding Jack, the story of hundreds of canine units left behind at the end of the Vietnam War. But of course, James Dean died in a car accident on 30 September 1955, almost a decade before US troops entered Vietnam. How then is he cast in a new film? The fascination for me is less about whether this film should or even can be made, and more to do with the insight this whole episode provides into wider social and legal perspectives on the performer and the art of performance.

Today, some 64 years later, the reanimation of James Dean has been promised by directors Anton Ernst ${ }^{1}$ and Tati Golykh ${ }^{2}$ in their announcement of Finding Jack, to be released through their production company, Magic City Films. Notably, their director credits are scant (although Ernst was a producer of Little One, the South African official submission to the Best Foreign Language Film category of the 85th Academic Awards, 2013). In fact, Finding Jack, will be the feature directorial debut for both Ernst and Golykh. However, even their short films have not yet been released, so as far as audiences are concerned, neither has as yet released a film as director. The first scheduled release, a short film co-directed by Ernst and Golykh entitled Three Stops, is currently in post-production.

The international press surrounding the announcement of James Dean's casting is out of all proportion to the modest profile of the film's team. However, the production team adds some experience with the inclusion of Donald A Barton, ${ }^{3}$ but even his work has been somewhat stalled for the last four years. Curiously, one of his production efforts, a reanimation horror entitled Re-Generator, ${ }^{4}$ suffered such production delays

1. <https://www.imdb.com/name/nm1132222/>.

2. <https://www.imdb.com/name/nm9132715/>.

3. <https://www.imdb.com/name/nm1247737/>.

4. Re-Generator (2010), Olivier Gruner and Patrick Shanavian (directors), One Night Production. 
that its release was several years after completion of filming. ${ }^{5}$ The film met with such universally bad reviews that it has no Rotten Tomatoes rating at all. ${ }^{6}$

Who would work with such an inexperienced and relatively unknown team? Indeed, according to the pre-production credits, only James Dean would. At the time of writing this, James Dean remained the only actor 'cast' in the film. ${ }^{7}$ The question is why?

James Dean was domiciled and died in California and, as such, his image still enjoys protection under Californian law. ${ }^{8}$ Although image rights are not recognized across all states in the US, and not recognized at all in the UK, ${ }^{9}$ in so far as any film would no doubt be subject to a national campaign in the US, then the effect of protection in one or more states could have an impact on the overall circulation of the film. Dean's image rights are managed by CMG Worldwide, which just happens to have merged with Observe Media to create Worldwide XR, ${ }^{10}$ which purports to trade in 'extended reality'. ${ }^{11}$ Mark Roesler, CEO of CMG Worldwide, ${ }^{12}$ is the new company's chairman and co-founder. Its business model, it seems, is to acquire the rights for as many deceased actors as possible so as to establish a stable of digital performers ${ }^{13}$ - somewhat of a modern perversion of the Studio System 2.0. Travis Cloyd, ${ }^{14}$ CEO of Worldwide XR, actually describes it as 'James Dean 2.0'.15

The film is thus to be directed by directors with no track record of direction, and not performed by an actor, but 'promoted' by a brand - James Dean. Ernst describes the character of Rogan as a 'very brilliant, complex character', and Dean as the 'perfect fit' because this is 'pretty much how James Dean was perceived'. ${ }^{16}$ This film is not so much concerned with performance as it is with biography. It is premised almost entirely upon branding. And in this respect it really is a kind of reanimation horror.

The response to the film's announcement was immediate and extensive in the popular media and industry press, and I was interviewed by journalists on how such a

5. Review: Re-Generator (2013), BZ Film, 14 May 2013, <https://bzfilm.com/reviews/ horror-syfy-film-reviews/review-re-generator-2013/>.

6. Rotten Tomatoes, Re-Generator, <https://www.rottentomatoes.com/m/re_generator $>$.

7. Finding Jack, IMDB.com page, <https://www.imdb.com/title/tt7176706/>.

8. California Civil Code $\S 3344.1$ (The Astaire Celebrity Image Protection Act). The issue is more complicated because other states, with two exceptions (Washington and Indiana), tend to apply a choice of law rule, which means that only those domiciled in California at the time of death have a right which is recognized in other courts: see Milton H Greene Archives Inc $v$ Marilyn Monroe LLC, 692 F.3d 983 (9th Cir 2012). This case precluded Marilyn Monroe from having any image rights in California as she was domiciled in New York at the time of her death. See further Shaw Family Archives Ltd v CMG Worldwide Inc, 486 F. Supp 2d 309 (SDNY 2007), the effect of which has now been overturned by an amendment to Californian law.

9. See Douglas v Hello! [2007] UKHL 21, [2008] 1 AC 1, para 124.

10. <https://www.worldwidexr.com/about/>.

11. <https://www.worldwidexr.com>.

12. <https://www.cmgworldwide.com/mark-roesler/>.

13. J Roettgers (2019) 'Team Behind Digital James Dean Forms New Company to Resurrect Other Legends', 12 November, <https://variety.com/2019/digital/news/james-dean-worldwidexr-1203401302/>.

14. <https://www.traviscloyd.com>.

15. Roettgers (n 12).

16. Anton Ernst quoted in S Drury (2019) 'Director of New James Dean Movie Speaks Out Over Backlash to Star's "Casting", Hollywood Reporter, 7 November, <https://www.hollywoodreporter. com/news/director-new-james-dean-movie-speaks-backlash-stars-casting-1253232>. 
manipulation of a screen icon could be possible within the law. ${ }^{17}$ But the actual legal aspects of this reanimation drama are perhaps a lot simpler, and certainly much less interesting, than the ways in which the legal framework is articulated through the wider social and cultural perspectives on creativity. In reality, as it were, the real challenge for reanimation is arguably not securing the image rights that may or may not apply, but rather, the copyright in the various elements (such as film cells and photographs) needed to achieve 'enaction' of the deceased performer. ${ }^{18}$ Arguably copyright is the much greater challenge for these reanimations than image rights. The right to reanimate is thus frequently not under the control of the original performer, but rather, is under the control of the director and producer - their animators, so to speak.

Speaking of speech, what about Dean's voice? It may be reconstructed from voice recordings, where artificial intelligence learns from recordings in order to voice new material, raising further potential copyright issues. Or it may be that the filmmakers use a voice artist to impersonate Dean. But in some US states, even impersonators of voice may infringe image rights where that voice is part of a performer's recognizable identity. ${ }^{19}$

In so far as the application of trade marks to extensive character merchandising is such a significant part of current franchise business models in the industry, there is a possibility of anticipating this kind of reanimation use, at least to the extent that an actor is especially identified with a particular role. Is the reanimation on brand?

But what would James Dean say? Although many have raised the question as to whether Dean would have consented to the role, or whether it is consistent with his own personal philosophical and ethical views, ${ }^{20}$ image rights notwithstanding, it is not possible to defame the dead. At least, not as far as the law is concerned. ${ }^{21}$

17. World Update, BBC World Service, 22 November 2019; A Lee (2019) 'The Messy Legal Scrap to Bring Celebrities Back from the Dead', Wired, 17 November, <https://www.wired.co. uk/article/james-dean-dead-actors-rights>.

18. James Dean's films are all still under copyright protection and so the ability to use film cells to 'reanimate' his performances would require the permission of the copyright holders for the respective films: East of Eden (1955); Rebel Without a Cause (1955) and Giant (1956). 19. Midler v Ford Motor Company, 849 F.2d 469 (9th Cir 1988).

20. In response to director Ernst's comment, 'We never intended for this to be a marketing gimmick', Geoffrey Macnab writes, 'It somehow eluded Ernst that Dean's short career (which ran to only three movies) had been based around an absolute refusal to compromise or cheapen his image to keep the studio bosses ("those bastards at Warners") happy'. See G Macnab (2019) 'Why Bringing James Dean Back from the Dead Through CGI is Proof of the Diminishing Allure of Today's Stars', The Independent, 15 November, <https://www. independent.co.uk/independentpremium/james-dean-finding-jack-cgi-rebel-without-a-causehollywood-a9201056.html>. See further K Fisher (2019) 'Resurrecting James Dean has Begun a Concerning Trend', 16 November, <https://filmschoolrejects.com/james-dean-digital-replace ment/>: 'Many of these performers worked to create legacies, to star in works they felt passionate about. If they made mistakes along the way, at least they did so under their own accord. Casting them in movies long after they've departed is not only disrespectful of their agency, but it risks tarnishing their legacies. It will be tragic if future generations base their opinion of Dean through his CGI zombie and not the performer who gave us classics like Rebel Without a Cause.'

21. Where this technology becomes more problematic on this question is in the creation of deepfakes of the living, such as in deepfake pornography and manipulated news and political information. Arguably, however, this is a completely different consideration and concern for the rights of a performer, but nevertheless an especially topical issue in the immediacy of the dissemination and consumption of information. See further D Fortson (2019) 'The Rise of 
But what about the tarnishment ${ }^{22}$ or reputation ${ }^{23}$ of a brand? And in this context, what about the perception of fans? What is their 'investment' in James Dean and how is this kind of cultural value memorialized and then monetized in the sort of enterprise pursued by Worldwide XR et al.? In other words, is this the authentic Dean? Conscious of the criticism, Ernst has declared, 'We do not intend to let the fans down'. ${ }^{24}$

On the other hand, perhaps the overriding theme that has dominated the discussion as it has played out in the media, whether in the context of any legal implications or otherwise, was that this represents a kind of perverse reanimation in almost every sense of the horror film sub-genre. The key elements of the reanimation film are identifiable in almost every media incarnation, as it were, of the issues raised by the prospect of CGI actors. The focus has been less on the re-use of existing footage and much more on the notion of reanimating James Dean himself. Does Finding Jack actually promise to be a zombie film 2.0? And is this development in film production less technological 'disruption' 25 and more the ultimate reanimation horror writ large?

In 1922, HP Lovecraft published 'Herbert West - Reanimator'. The story was serialized in six installments in the magazine, Home Brew. Although the story is widely viewed as Lovecraft's weakest work, it has arguably shaped a genre and incited an enduring preoccupation with the possibility of reanimation and the persistent fascination with zombies in popular culture. The story has been referenced and adapted widely, including famously in the film Re-Animator, ${ }^{26}$ a horror comedy released in 1985 to generally positive reviews and ultimately achieving cult status.

The protagonist of the classic reanimator genre film is the 'mad scientist' (whether an individual or a malevolent corporate or government entity). This figure is obsessional and devoid of ethical limits, led by grandiose ambition towards a seemingly inconceivable goal that is pursued with messianic zeal. The scientific investigation of reanimation is characteristically represented as taboo, studied in secret: 'West's sole absorbing interest was a secret study of the phenomena of life and its cessation.' Described as anything from a 'concerning trend' 27 to 'playing god', ${ }^{28}$ the response to the CGI James Dean includes all the classic motifs of the reanimation film. As one journalist asks, "If we're skeptical of humans "playing god" as far as certain aspects of gene-editing goes, why not apply the same skepticism to the technology we consume? ${ }^{29}$ Is this new kind of reanimation movie, as it were, 'playing god' with the lives of performers?

Deepfakes: What are They and How can We Know What's Real?', The Sunday Times, 22 December, <https://www.thetimes.co.uk/article/the-rise-of-deepfakes-what-are-they-andhow-can-we-know-whats-real-x03jp3rqr>.

22. 15 USC $\S 1125(\mathrm{c})(2)(\mathrm{C})$.

23. In the EU the law is as to detriment to the repute of a brand: Regulation (EU) No 2017/1001, art $9(2)(\mathrm{c})$.

24. Anton Ernst quoted in A Singh (2019) 'Casting James Dean in a Movie is About More than Consent - We Need to Talk about the Dwindling Ethics of AI', The Independent, 9 November, <https://www.independent.co.uk/voices/james-dean-finding-jack-ai-cgi-ethicshollywood-a9196251.html $>$.

25. Travis Cloyd, CEO of Worldwide XR, describes it as 'disruptive' in J Roettgers (2019) 'Team Behind Digital James Dean Forms New Company to Resurrect Other Legends', Variety, 12 November, <https://variety.com/2019/digital/news/james-dean-worldwide-xr$1203401302 />$.

26. Re-animator (1985), directed by Stuart Gordon.

27. Fisher (n 20).

28. Singh (n 24).

29. Ibid. 
In Lovecraft's words, this kind of reanimation risks turning performers into mere specimens. Indeed in Cloyd's unapologetic words, performers are 'assets' ${ }^{30}$ What then of the performer? In a question almost perfectly resonant with the reanimation genre, one LA acting teacher asks, 'Is there something human underneath?' ${ }^{31}$ Just as the narrator, in his assistance to Herbert West, secretly investigates what 'consciousness' underpins creativity in order for not only the law but also society to consider it as 'art'? In Lovecraft's story, 'West was a materialist, believing in no soul and attributing all the working of consciousness to bodily phenomena', but his assistant, the narrator, could not help asking, 'Where have you been?', to which he believes the subject mouthed the words, 'only now'.

In the reanimation, the 'specimen' becomes an ahistorical being - no past, no present, no question of provenance or creative narrative, just an asset for and ultimately an artefact of West's investigations. Indeed, it is perhaps this aspect that influences the key questions surrounding not only CGI actors, but also artificial intelligence and other forms of 'reanimation' of creative endeavour. In some respects, the creative hierarchy of the 'work' of performance, of copyright, is the 'taboo' question for copyright. In many respects, performance is a kind of 'diminished' version of the artistic work, with less protection and greater uncertainty. ${ }^{32}$ Conceptual art may elude copyright altogether. ${ }^{33}$ So what then of the artist? The hierarchy of different kinds of creativity that is implied through copyright says much more about the artist than about the art. The unspoken taboo of copyright is the creativity of the performer and the 'work' of performance. The reanimator always gets in the way.

A tweet by the actor, Chris Evans, captures this hierarchy in 140 characters or fewer. The tweet was repeated many times throughout the various reports: 'This is awful. Maybe we can get a computer to paint us a new Picasso. Or write a couple new John Lennon tunes. The complete lack of understanding here is shameful. ${ }^{34}$ Although Microsoft is trying to do just this in 'The Next Rembrandt', ${ }^{35}$ nevertheless, this implication of a creative hierarchy (as between painting, literature and performance) also goes to the heart of enquiry into the potential authorship of machines. It is not a question of 'who' might be able to hold rights, it is a question of 'what' might excite those rights.

30. 'Essentially our job is to protect the best interests of the family's [sic] that we work with. You never know what's going to happen with those assets. Our intention is to protect and to create': Travis Cloyd quoted in Lee (n 16).

31. Allen Barton, acting teacher with the Beverly Hills Playhouse, quoted in C Toto (2019) 'James Dean's "Return" to Big Screen Draws Mixed Reviews: "Is There Something Human Underneath?", Washington Times, 14 November, <https://www.washingtontimes.com/news/ 2019/nov/14/james-dean-finding-jack-simulation-draws-mixed-rev/>.

32. See Directive 2006/115/EC arts 7-11 and art 3; Directive 2001/29/EC arts 2 and 3. In the US performers' rights do not exist in any meaningful way: see Garcia v Google, 786 F.3d 733 (9th Cir 2015). See further P Johnson and S Halpern, 'When is a Performance Not a Performance (but a Copyright Work)?' (2014) 4 Queen Mary Journal of Intellectual Property 236.

33. For instance, in olfactory or smell art, and similarly sound art, legal protection of the art may be achieved through ways deferred from the original premise (although this varies between jurisdictions, some examples may include the receptacle and installation for smell art, the recording of sound art, or the physical apparatus for sound art). See further on smell art, J Gibson, Owned, an Ethological Jurisprudence of Property (Routledge, London 2019), Chapter 6. See also an introduction to the issues around the exhibition of sound art in M Carrigan, 'How Do You Exhibit Sound Art?', Artsy, 5 October 2017, <https://www.artsy.net/article/artsy-editorialexhibit-sound-art>.

34. Chris Evans, Twitter @ ChrisEvans, 6 November 2019, <https://twitter.com/chrisevans/ status/1192137540842733568?lang=en>.

35. See further $<$ https://www.nextrembrandt.com $>$. 
Artificial intelligence art is the new sparkly toy for intellectual property lawyers everywhere. There appears to be no hesitation in recognizing the authorship of machines in respect of works that are deemed to be 'authentic' in the eyes of society and of the law - that is, traditional artistic works. Indeed, the 2018 auction sale of the AI artwork, Edmond de Belamy, from La Famille de Belamy, for US\$432 500, ${ }^{36}$ shows the plausibility of the creative narrative where the more 'traditional' painting itself is willingly accepted as a work and thus as 'authored'. In the case of artificial intelligence, the 'author' is constructed out of what are easily interpreted as conventional copyright works and control is somewhat eagerly and readily attributed to the ultimate human in control - the reanimator, if you will. It does not seem to matter what the author is; the important question is that of the work that makes the author. If we recognize a work, we can conceive an author. Would we be having this same conversation if the subject were an AI performer? Performances simply do not make artists, at least as far as the extent to which the law might interpret the authenticity of a work. It may be art, but is it copyright?

Returning to the question of defamation then, the consideration of a performer's 'legacy' ${ }^{37}$ is not immaterial in that the public perspective of that legacy is something towards which the performer exercised autonomy, agency and a kind of personal authorship. Indeed, Ernst acknowledges this, but then recasts it, as it were, in terms of the endurance of a brand: 'I think they would have wanted their family member's legacy to live on. That's what we've done here as well. We've brought a whole new generation of filmgoers to be aware of James Dean. ${ }^{38}$ Arguably, this statement betrays the emphasis on creating a new generation of brand awareness, not a new generation of audiences for James Dean films.

But who is the performer? Is this even a performance? And such a lucrative one for the reanimator. Just as in the HP Lovecraft story, Dean is set to be reanimated without a brain. West sought to find out 'whether any amount of consciousness and rational action be possible without the brain'. It would seem that Worldwide XR seeks to do the same. There may be something human underneath, but it is not James Dean. The ultimate control of Dean rests with the reanimator.

In the classic reanimation film there is always a consequence for dabbling in the taboo and interfering with the 'natural order' of things, of history, and in this case, of performance. As Zelda Williams, daughter of the late actor, Robin Williams, tweeted, 'it sets such an awful precedent for the future of performance'. ${ }^{39}$ We might do well to take heed of the words of West's assistant, the narrator of Lovecraft's story, 'Memories and possibilities are ever more hideous than realities'. Instead of managing deepfakes, might we not regard performers?

Where have you been, James Dean?

Johanna Gibson

December 2019

36. A Elgammel, 'What the Art World Is Failing to Grasp about Christie's AI Portrait Coup', Artsy, 29 October 2018, <https://www.artsy.net/article/artsy-editorial-art-failing-grasp-christiesai-portrait-coup $>$.

37. Fisher (n 19).

38. Anton Ernst quoted in Drury (n 15).

39. Zelda Williams, Twitter @ZeldaWilliams, 6 November 2019, <https://twitter.com/zelda williams/status/1192141551171854338?lang=en-gb>. 